\title{
Gender and Medical Inspections at Ellis Island
}

\author{
Letitia Johnson
}

For many immigrants to the United States, between 1892 and 1924, admission was contingent upon a medical inspection at an immigration centre, such as the one located at Ellis Island in the harbour of New York City. Much like passing through customs or security at airports today, these medical inspections were dreaded by immigrant travellers, and United States Government and Public Health Service (PHS) publications show that these medical inspections were escalating in intensity and emphasis during the early twentieth-century. The purpose of the PHS inspections becomes especially evident when looking at the gender considerations, or lack thereof, which arose during medical inspections at Ellis Island. A gender analysis of the PHS medical inspections, examined through the use of oral histories and photographs, provides a window into understanding the primary concern of the United States Public Health Service.

Between 1892 and 1924 many immigrants coming to the United States faced a medical inspection at immigration centres like Ellis Island in the harbour of New York City. Ellis Island was opened as an immigration centre in January 1892 at a time when medical inspections had become routine procedures at all official American ports of arrival. Much like passing through customs or security at airports today, these medical inspections were usually dreaded by immigrant travellers. The medical inspections were performed by the United States Public Health Service (PHS) and from the perspective of the PHS and other American officials the inspections served as a first line of defense in protecting the citizens of America from illness. This goal of the PHS medical inspections at Ellis Island appears to be true and evident when looking at the way in which the PHS used gender as a tool during medical inspections at Ellis Island. How, why, and when the medical inspections were, or were not, conducted differently for female or male immigrants provides a window into understanding the primary concern of the PHS, which arguably was to ensure that immigrants would not become a threat to the health of Americans.

By the time Ellis Island was designated, renovated, and run by the Immigration Bureau for the purpose of immigrant screening, medical inspections had become routine at all official American ports of arrival. However, the purpose of the immigrant medical inspections was altered when the federal government assumed responsibility for public health by the turn of the century. ${ }^{1}$ Based on this new responsibility the federal government managed immigration centres, and by association the medical inspections conducted at such centres. The main concern of the

\footnotetext{
${ }^{1}$ Alan Kraut, "Doing as Americans Do: The Post Migration Negotiation of Identity in the United States," Journal of American History, 101 (2014): 712, accessed on February 1, 2015, http://login.ezproxy.library.ualberta.ca/login?url=http://search.ebscohost.com/login.aspxdirect=true \&db=hlh\&AN=1 $\underline{01035136 \& \text { site }=\text { eds-live } \& \text { scope }=\text { site }}$
} 
government was to ensure that immigrants would not become dependent upon the state as "public charges." 2 Within these parameters, a multitude of government departments, such as the Immigration Bureau and the PHS, conducted their business out of Ellis Island. One important figure in the establishment of Ellis Island's immigration inspections and procedures was the Commissioner of Immigration for the Port of New York, William Williams. Williams served two terms as Commissioner (1902 to 1905 and 1909 to 1914). He was instrumental in the growth of Ellis Island both physically and in terms of the efficiency and form of inspections carried out by the PHS at the Ellis Island immigration centre. ${ }^{3}$

The physicians who carried out the medical inspections at Ellis Island were part of the PHS, which evolved from a federal program created in 1789 to provide care to merchant seamen coming to the United States. ${ }^{4}$ Initially named the United States Marine Hospital Service, the service was renamed the United States Public Health and Marine Hospital Service in 1902 and then became the United States Public Health Service in $1912 .^{5}$ The service was organized in a military fashion, complete with military-style rank and uniforms. ${ }^{6}$ The PHS officers managed the institutional additions to Ellis Island, such as the General Hospital (1902), Psychopathic Pavilion, and Contagious Diseases Hospital (1911), and were responsible for the medical inspection and potential detention of up to 5,000 immigrants per day at Ellis Island. ${ }^{7}$ Over the course of Ellis Island's use as an immigration centre PHS officers adapted to advances in the medical institutions available at Ellis Island, which corresponded to developments in American science and medicine as well as cultural shifts towards increasingly respecting the unquestioned authority of orthodox medicine in the United States. ${ }^{8}$

Though Ellis Island was used for a multitude of immigrant inspections, such as questioning by the Immigration Bureau regarding economic factors, the medical inspection was the first and often remembered as the most traumatic inspection that immigrants experienced. Overall, a gender analysis of the medical inspections at Ellis Island provides evidence of the purpose of the medical inspections as a whole, evidence which is inline with the mandate of the military-like PHS officers, which was to ensure the health and safety of the American people was protected first and foremost. Gender provides a social construct through which to view the medical inspections in lieu of other traditional social divisions, such as class and race divisions, which were not officially used as dividing factors at Ellis Island. However, though class and race were not officially regarded in the PHS mandate at Ellis Island, there is evidence of their impact.

2 Quoted in Alan Kraut, Silent Travelers: Germs, Genes and the 'Immigrant Menace, '(New York: Basic Books/Harper Collins Publishers Inc., 1994), 51.

${ }^{3}$ Lorie Conway, Forgotten Ellis Island: The Extraordinary Story of America's Immigrant Hospital, (New York: Harper Collins, 2007), 6-7.

${ }^{4}$ John Parascandola, "Doctors at the Gate: PHS at Ellis Island," Public Health Service Chronicles: Public Health Reports, Historical Perspectives on Public Health Issues. 113 (1998): 83.

${ }^{5}$ Kraut, Silent Travelers, 60.

${ }^{6}$ Parascandola, 83.

${ }^{7}$ Conway, 8; Kraut, Silent Travelers, 54.

${ }^{8}$ Elizabeth Yew, "Medical Inspection of Immigrants at Ellis Island 1891-1924," Bulletin of New York Academy of Medicine 56 (1980): 488, accessed on March 4, 2015, http://www.ncbi.nlm.nih.gov/pmc/articles/PMC1805119/ 
First, the medical inspections on Ellis Island were unequivocally a class issue. In fact, the medical inspections conducted on Ellis Island were only performed on Third Class or Steerage steamship passengers. First and Second Class passengers were similarly inspected by PHS officers; however, their inspections took place onboard their respective steamships. Therefore, in the privacy and cleanliness of their personal cabins, First and Second Class passengers were mostly exempt from the frequently traumatic experience of passing through Ellis Island. ${ }^{9}$

In addition to the class-based inspections, there were racial stereotypes which persisted at the immigration centre for most of Ellis Island's existence as well. Realities of the wealth of certain nation-men and women, and the emigration trends of the era, meant that certain racial groups were more prominently represented at Ellis Island than others. For example, southern and eastern Europeans are statistically more prominent in the records of those who passed through Ellis Island. Even though this was based on the reality of who frequented Third Class and Steerage cabins in the early twentieth century, it constitutes a racial element to the story of inspections at Ellis Island which should be considered. ${ }^{10}$ However, it is important to remember that regardless of the factors of race or class which brought certain immigrants to Ellis Island, those who passed through were subjected to similar medical examinations.

An immigrant's day at Ellis Island would begin by disembarking a ferry which brought him or her to Ellis Island from a steamship. Immediately they would be ushered into the immigration centre's main building. Then, immigrants would be further instructed to ascend the stairs which would bring them into the "Great Hall" or registry room. Probably unbeknownst to many immigrants, the medical inspection had begun. PHS officers began a hasty, visual line inspection by observing immigrants as they climbed the stairs to the Great Hall, while carrying their belongings, and often young children, in their arms. The visual line inspection continued with a team of PHS officers inspecting the hands, throat, and heart (by taking the pulse) of immigrants as they reached the top of the stairs. ${ }^{11}$

Then, immigrants went to another officer who would inspect their eyes, looking specifically for trachoma or other contagious eye diseases. ${ }^{12}$ Once the eye-lids of immigrants were inspected by use of the PHS officer's fingers or button-hooks, the immigrants were given an immigration card to hold. This too was part of the carefully constructed medical inspection, as the reactions of immigrants were judged by PHS officers. PHS officers used this 'card trick' to judge further eye deficiencies in the immigrants they examined. ${ }^{13}$ Every aspect of the line progression was

${ }^{9}$ Kraut, Silent Travelers, 53. Note that $1^{\text {st }}$ and $2^{\text {nd }}$ class passengers may have come to Ellis Island if sick also. And perhaps the "togetherness" of third class was more normal for third class passengers, as this is how they had travelled to America by steamship. This would require more in depth analysis of the patient's experience and maybe that would reveal that the individual exams were the most stressful.

${ }^{10}$ Addressed at various points in chapter 3 of Kraut, Silent Travelers.

${ }^{11}$ Kraut, Silent Travelers, 54. The "top of the stairs" and the magnitude of the 'great hall' is illustrated in Figures 3 and 4.

${ }^{12}$ David Brownstone, et al., Island of Hope Island of Tears, (New York: Rawson, Wade Publishers, Inc., 1979), 159. These eye exams are illustrated by Figure $1-2.1$ in Appendix 1. For a description of the medical condition of trachoma, see: "Trachoma," Medline Plus, Accessed April 3, 2015.

http://www.nlm.nih.gov/medlineplus/ency/article/001486.htm. And for more on the specific conditions PHS officers would look for in order to detect this contagious disease, see: Kraut, Silent Travelers, 55.

${ }^{13}$ Kraut, Silent Travelers, 55. 
intentionally designed so that a PHS officer could visually scrutinize the health of an immigrant. Even the design of the line itself, through the use of metal barriers which moved immigrants through like cattle, was constructed for the PHS officers to make quick decisions about an immigrant's health. For example, two right-hand turns aided this hasty inspection as they allowed the PHS officers to view both sides of an immigrant's face and body, allowing for detection of deformities. ${ }^{14}$

Additionally, the line inspection was influenced, perhaps more than other aspects of the PHS medical inspections, by the American public and their general concern over particular diseases which were reaching America. One example of a public sentiment which influenced the PHS greatly was a statement by U.S. Commissioner General of Immigration, Terrence Powderly. In 1902 Powderly spoke out against the negative impact of immigrants with contagious diseases reaching American soil. He called upon fellow Americans to recognize the risks of permitting diseased immigrants into America. His view that Americans should refuse to let their nation become "the hospital of the nations of the earth" significantly impacted the ways in which all immigrants were inspected for contagious diseases. ${ }^{15}$

Based on the combination of the physical aspects of the line inspections and the influential opinions of Americans, immigrants were separated by a chalk mark after their line inspections. Those who had been marked on their right shoulder with chalk were suspected of various health ailments. Those who had not been marked were not suspected by the PHS officers as having ailments which would threaten the public health of Americans. These immigrants would pass onto another holding area where they would await their turn to be questioned by Immigration Bureau Officers who, like the PHS officers, would conduct an inspection which would determine if the immigrant would be detained for further questioning or admitted to the United States immediately. ${ }^{16}$ For the immigrants who passed through these various examinations without concern from either the PHS or Immigration Bureau, their stay on Ellis Island could be less than five hours. ${ }^{17}$ Others would not have such a short experience.

Immigrants who had been chalk-marked during the line inspection were detained in holding areas, separated into sections for specific ailments, where they awaited further medical examinations. ${ }^{18}$ Some were even kept for subsequent hospitalization at Ellis Island, should they be deemed 'curable' and should they be able to secure payment for such care. ${ }^{19}$ At this point in the medical examination gender became considered a factor. Not only were immigrants separated by suspected medical ailments, but they would also be separated by gender. One out of

\footnotetext{
${ }^{14}$ Conway, 32.

${ }^{15}$ Terence V. Powderly, "Immigration's Menace to the National Health,” North American Review, 1902: 53-60, in Major Problems in the History of American Medicine and Public Health, ed. John Harley Warner and Janet A. Tighe (Boston: Houghton Mifflin Company, 2001), 241-244.

${ }^{16}$ Kraut, Silent Travelers, 55.

${ }^{17}$ Ibid., 54.

${ }^{18}$ Ibid., 55.

${ }^{19}$ This is another interesting aspect of gender, race, and class implications which goes beyond the scope of this paper but is discussed by many of the historians listed in the bibliography, such as Kraut. The payment for hospitalization usually involved the help of various immigrant aid societies (like the Hebrew Immigrant Aid Society or HIAS), which is also discussed in Kraut's work.
} 
five immigrants on average would be subjected to detainment for further visual medical inspection. ${ }^{20}$ Of this twenty percent of immigrants, one percent or less on average were detained for hospital care, which was conducted on Ellis Island (Islands No. 2 and 3) after 1902. ${ }^{21}$

Gender was very much a factor which was decisive in determining how the medical inspections at Ellis Island were conducted and, more specifically, where medical inspections were performed. The PHS's primary purpose, to protect the public health of Americans, is evident by examining gender in relation to the inspections first as a differentiating factor, then as an inclusive factor. First, through consideration of oral histories which demonstrate the aspects of the medical inspection which were gender conscious, it is evident that the PHS medical inspectors were aware of differing factors which would make each gender a potential threat to the public health of the nation. As such, sex segregated inspections were conducted by the PHS in order to best facilitate protecting American public health from commonly gender-associated diseases. Second, through an examination of PHS commissioned photographs, an opposite consideration of the medical inspection as gender inclusive is deduced. This further emphasized how the PHS's purpose was ultimately to protect the health of Americans. Both ways of viewing gender as a factor in the medical inspections demonstrated that the PHS was acting in order to protect the health of Americans first.

For some parts of the medical exam, gender was a separating force. Should immigrants be detained for further medical examinations, men and women were separated and inspected in gender-respective rooms with other immigrants. This separation of the sexes for visual medical exams was because of, and in-line with, sexual conventions of the early twentieth century. ${ }^{22}$ But another reason for the sex segregated medical examinations can be seen through immigrant accounts of medical inspections at Ellis Island. One such account was provided by the Irish immigrant Emanuel (Manny) Steen. Manny's memory of Ellis Island was not unlike many other immigrants. He was nineteen when he passed through Ellis Island, and his recollection of the medical inspection provides insight into the conduct of the PHS in the early twentieth century.

Manny remembered:

I think, frankly, the worst memory I have of Ellis Island was the physical because the doctors were seated at a long table...and you had to, uh, reveal yourself. Right there in front of everyone, I mean, it wasn't private! And the women had to open their blouse...I was nineteen and I was embarrassed as hell, you know. I had to open my trousers and fly and they would check you for venereal disease or hernia or whatever they were looking for. I felt this was very demeaning... [it's] a very

\footnotetext{
${ }^{20}$ Conway, 34.

${ }^{21}$ Thomas Pitkin, Keepers of the Gate: A History of Ellis Island, (New York: New York University Press, 1975), 73. And up to two percent of immigrants (again, of the twenty percent detained for further medical exams) could face deportation on a daily basis based on health concerns.

${ }^{22}$ Kraut, Silent Travelers, 55.
} 
unpleasant memory and I just thought they didn't have to do it that way. ${ }^{23}$

The different inspections which Manny details for men and women explains how gender became important in deciding what would be considered a threat to the health of Americans. Manny noted that he was checked for venereal diseases and "had to open [his] trousers and fly", while women, he remembered, had to open their blouses. ${ }^{24}$ This suggests a differentiation in the ailments which PHS officers inspected female and male immigrants for. However, Manny's recollection leaves room to question whether he saw the women removing their blouses for medical inspections or if he just knew of this experience through second-hand knowledge, from fellow immigrant's stories. Also, this recollection leaves room for further investigation of what exactly the PHS was looking for when they made female immigrants remove their tops. But, ultimately, recollections of Ellis Island and medical inspections such as Manny's suggest a differentiation in the ailments which PHS officers inspected female and male immigrants for during their visually-based medical examinations. Men, like Manny, remembered being examined for venereal diseases whereas women do not generally associate their medical inspections with the specific inspection of this potential disease category. ${ }^{25}$ In fact, by 1917 "the groins of all male immigrants and assessment of pupillary light reflexes to detect syphilis were included" in the medical inspection of male immigrants at Ellis Island. ${ }^{26}$ Indeed, most women who were expected of being a sexual threat to Americans, diseased or not, were deported on the basis of being a prostitute and no further explanation was needed. Yet, men were inspected for venereal diseases increasingly after World War I. ${ }^{27}$ This suggests that the PHS's concern for potential health threats to Americans was gender specific in the case of venereal diseases which men could be inspected for visually, during an additional inspection added to the more inclusive aspects of the line inspection. Because of the anatomy of male immigrants, they were exposed to the visual inspection for venereal diseases during the medical inspection whereas women were not. This was one of the ways in which gender played a role in the PHS medical inspections at Ellis Island. However, this also illustrates one of the shortcomings of a visual medical inspection because it largely limited the PHS officers to inspecting males for venereal diseases and left them with little to no way to inspect female immigrants for venereal diseases during the initial line inspection process.

Other aspects of the medical inspections were similarly dictated by gender considerations which enabled the PHS to protect the public health of America. Who was present for the medical examination and who the examination was performed by were contingent on the gender of immigrants. And, for the immigration centre at Ellis Island, this "presented a particular challenge" when examining female immigrants. ${ }^{28}$ Examinations by male doctors were commonly a traumatic experience for female immigrants. However, such exams were inevitable for a time

\footnotetext{
${ }^{23}$ My emphasis. EI-033, Emanuel (Manny) Steen, March 22, 1991. Interviewed by Paul E. Sigrist. U.S. National Park Services, Ellis Island, Oral History Online. Accessed on March 4, 2015. http:/www.nps.gov/elis/learn/historyculture/upload/Manny_STEEN.pdf

${ }^{24}$ EI-033, Emanuel (Manny) Steen.

${ }^{25}$ As is deduced by looking through the various available oral histories, online and in texts.

${ }^{26}$ My emphasis. Yew, 496.

${ }^{27}$ Kraut, Silent Travelers, 67.

${ }^{28}$ Parascandola, 84.
} 
as the first female physicians were not hired by the PHS at Ellis Island until 1914. Before this date, a ward matron or female nurse would be present for the semi-private medical examinations of female immigrants. ${ }^{29}$

Additionally, if immigrants were to be detained for further treatment, the hospital structure at Ellis Island was divided by gender as well. Immigrants who had contagious diseases or other medical reasons that delayed their admission to the United States were given the option of staying at the hospitals at Ellis Island or, in most cases where immigrants could not secure funding to remain at the Ellis Island hospitals, they were forced to return to Europe. Josephine Garzieri Calloway from Italy, who contracted trachoma before arriving in the U.S.A., was sent to the hospital at Ellis Island and her record of this hospital stay reflects the gendered nature of the medical institutions at Ellis Island. Josephine, for example, remembered being detained with her brother in the Contagious Disease Hospital on Island No. 3. She stated that "[her] brother...was on the lower level and [the women] were on the second story of another building." ${ }^{30}$ Here too it was evident that gender was considered during medical procedures at Ellis Island. Thus considered together, Manny and Josephine's personal stories of their experiences at Ellis Island show that the PHS was respectful of the sexual conventions of the early twentieth century, while also considerate of certain gender specific disease concerns which could arise. This suggests, moreover, that the PHS was acutely aware of the various diseases which men or women could be visually assessed for initially and in subsequent medical exams on Ellis Island, and as such the PHS inspected immigrants accordingly.

However, the opposite of these gender distinct considerations by the PHS was the initial gender inclusive aspect of the medical examination, during the initial line inspection of immigrants at Ellis Island. By looking at the line inspection in terms of this gender inclusion, and beyond the previously examined gendered differences at Ellis Island, the inclusive aspects of the line inspection revealed the purpose of the PHS medical inspection as a whole. As was previously illustrated, "each step [was] studied" as an immigrant came into the main immigration centre at Ellis Island. ${ }^{31}$ The inspection line was very much akin to an assembly line in which gender was not a primary concern, except in the few cases where a female or male immigrant was studied for a particularly obvious gendered medical condition, such as pregnancies for female immigrants or the previously discussed venereal diseases evident with male immigrants. ${ }^{32}$ By 1905 , all immigrants who passed through Ellis Island were subjected to some form of the line inspection. ${ }^{33}$

${ }^{29}$ Ibid., 84.

${ }^{30}$ EI - 193, Josephine Garzieri Colloway, June 17, 1986, interviewed by Judith Hartman, U.S. National Park Services, Ellis Island, Oral History Online, accessed on February 25, 2015. http://www.nps.gov/elis/historyculture/upload/Josephine_Garzieri_CALLOWAY.pdf

${ }^{31}$ Conway, 32.

${ }^{32}$ Pregnancies interestingly were a heavily contested condition and the rejection or the acceptance of a pregnant woman was left (more than any other ailment) to the discretion of the PHS officer examining her. This would be another aspect of the examination which would likely provide insight into the PHS' mandate to protect America's public health over the health of others or the economic concerns of immigration.

${ }^{33}$ Kraut, Silent Travelers, 61. 
And, even though the line inspection was "necessarily brief and superficial" it also proved to be particularly effective in detecting medical ailments. ${ }^{34}$

Technology, experience of PHS officers, and public sentiment all converged in the line inspection at Ellis Island. ${ }^{35}$ This becomes evident when examining the inclusive nature of line inspections at Ellis Island. Not only do PHS line inspections demonstrate a respect for the public opinion of health concerns, but they also acted in a sweeping manner in order to detect potential threats across gender, race, or class differentiations. In this way, the PHS is seen as protecting and serving the American public first, rather than emphasising the concern of immigrant health needs.

Photographs, commissioned by the PHS, are an important historical source for discovering the details and purpose of these PHS line inspections at Ellis Island. By closely examining photographs of the line inspections in particular, it becomes evident that initial line inspections were mostly gender inclusive. At a basic consideration, the images available of the line inspections at Ellis Island show men and women, together, waiting for an inspection. And, as these are mostly PHS commissioned and therefore feasibly constructed images, these photographs did not attempt to portray gender separation during the initial line inspection, which further suggests the inclusive nature of the line inspection. Additionally, some of these images were published in newspapers, which only further emphasises that this line inspection was truly inclusive in nature and the PHS did not attempt to hide this fact from the general American public who would see the images. ${ }^{36}$

Figures 3 and 4 of appendix I illustrate the way in which immigrants arrived in the "Great Hall" at Ellis Island. This was in an inclusive fashion, with immigrants arriving at the top of the stairs alongside other men, women, and children of all ages. Figures 1 and 2 illustrate the inclusive nature of the trachoma inspections, which occurred as a last step, at the end of the line. All these images show men and women together from the beginning of the line inspection to the last step in line, the trachoma eye inspection. Therefore, even more so than the gender conscious aspects of the medical examination, the line inspection demonstrated the PHS's concern for the health of Americans, rather than the immigrant's needs for health care. By looking at the gender, race, and class inclusive line inspection it is evident that the PHS was primarily concerned with the potential threats all immigrants could pose to the health of Americans. Combined with the reflective nature of public sentiment, which the line inspection was formulated upon, this aspect of the PHS medical inspection demonstrated a clear primary concern for the health of American citizens before others, such as the immigrants themselves.

The inclusive nature of these initial line inspections of immigrants provides an interesting opposite perspective to the gender distinct medical examinations which often followed, or were added to the line inspection through the early twentieth century. As the Ellis Island PHS medical inspection was, and continues to be, commonly associated with gender distinctions throughout

\footnotetext{
${ }^{34}$ Parascandola, 84.

${ }^{35}$ Kraut, Silent Travelers, 68; Yew, 496.

${ }^{36}$ For details on the publishing of each individual image see the LOC website links for each image. Some used here were published in newspapers; others were for official PHS records. There are also many others not included in the appendix that were published in New York newspapers, alongside journal articles about the purpose of Ellis Island.
} 
the entire process, it is valuable to consider the aspects which were not contingent upon gender. Because of the nature of what the line inspection was intended to detect and prevent from entering the USA, this aspect of the medical inspection at Ellis Island is valuable to understanding the primary purpose of the medical inspection as a whole. Unlike the visual medical examination which often followed, the line inspection did not differentiate and therefore in an even more obvious fashion, demonstrated what the true purpose of the PHS inspections was. By looking at this aspect of the medical inspection it becomes even clearer that the PHS was serving to protect the health of American citizens first. Ultimately, the physicians of the PHS saw their duty as guarding America from the 'enemy', which is identified as diseases and debility which could threaten the health of American citizens. ${ }^{37}$ Arguably, this is a legacy of the United States Public Health Service that continued into the early twenty-first century. ${ }^{38}$

Considered together, both the aspects of the PHS medical inspections which used gender in a differentiating manner and those aspects which did not provide valuable insight into how and why the medical inspection of immigrants was performed. Even though social factors and realities of class and race influenced who would pass through Ellis Island, it was the PHS's ability to choose when to make use of gender distinctions during their visual medical examinations which demonstrates the primary purpose behind their inspections. By looking at the way in which the PHS used gender as a tool, prioritizing how and when gender would be considered a factor, it is evident that the Public Health Service physicians at Ellis Island constructed their medical examination in order to fulfill their primary mandate: to protect the health and well-being of American citizens.

\footnotetext{
${ }^{37}$ Kraut, Silent Travelers, 57.

${ }^{38}$ Perhaps here one could consider the PHS controversies over the recent Ebola crisis. For more, see Howard Markel, "Before Ebola, Ellis Island's terrifying medical inspections," PBS News Hour, October 15, 2014, accessed March, 4, 2015. http://www.pbs.org/newshour/updates/october-15-1965-remembering-ellis-island/
} 


\section{Appendix 1 - Photographs}

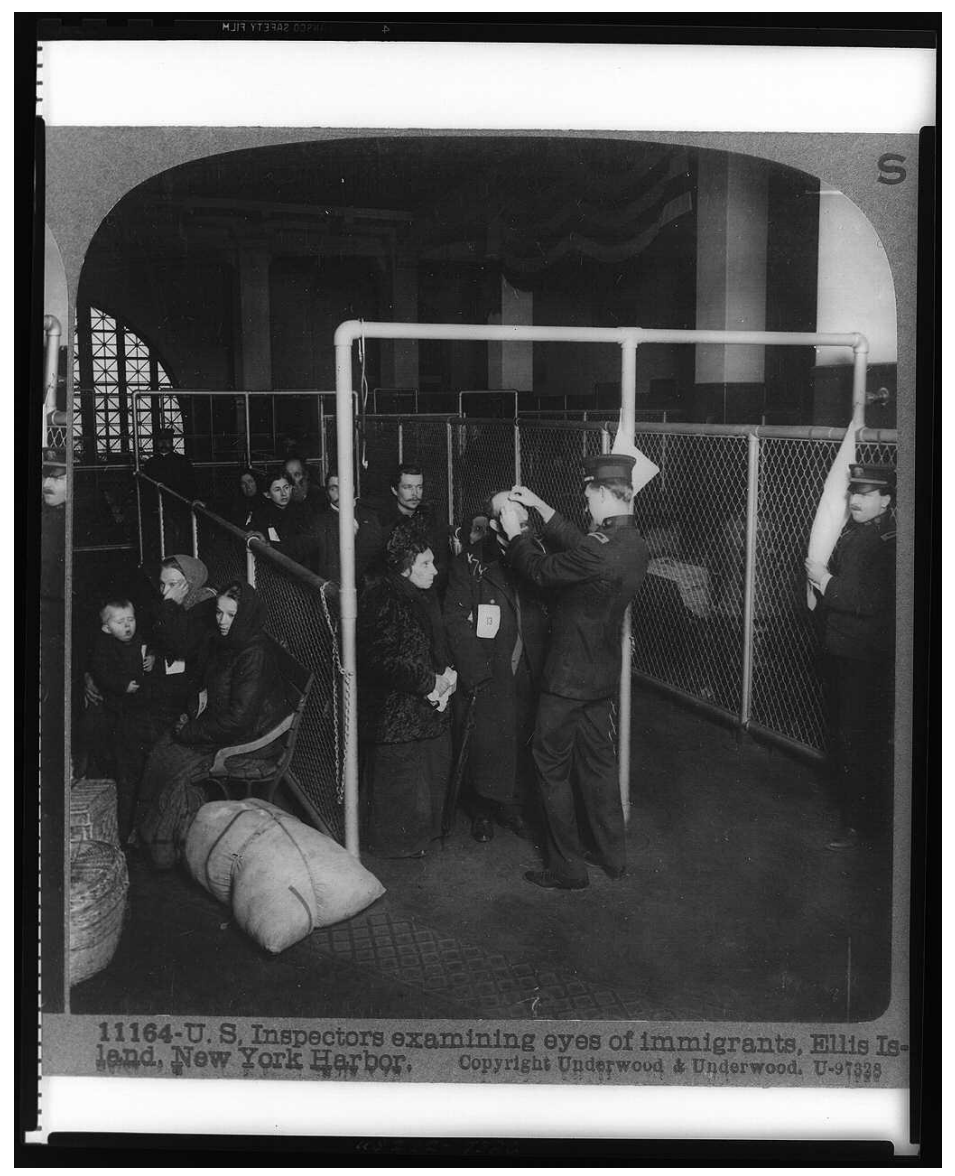

Figure 1 - Note the Cloths Being Used by the PHS Officers to Sanitize Fingers and the Woman Sitting Next to the Inspection Line Wiping Her Eye. 


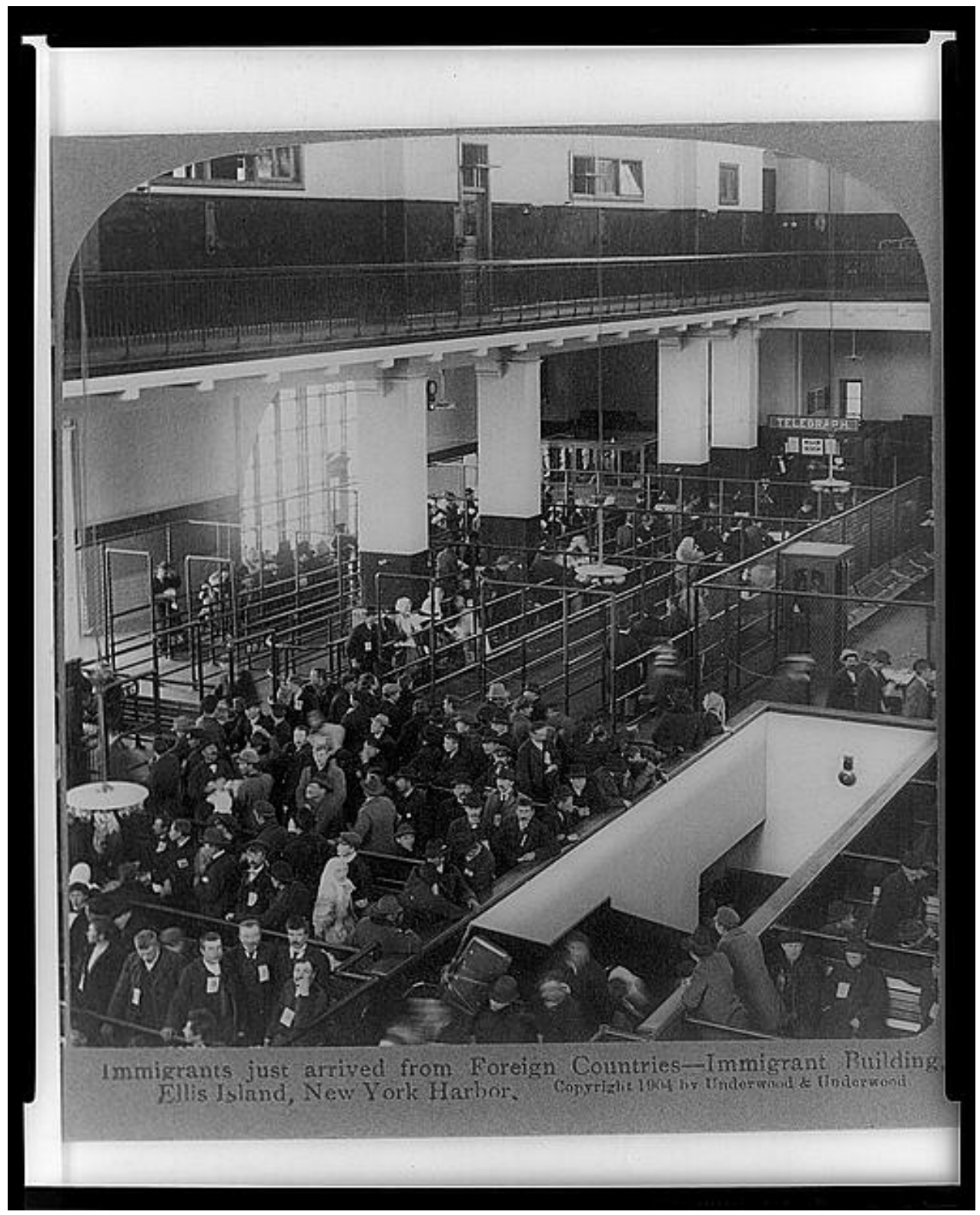

Figure 2 - Immigrants just arrived from Foreign Countries - Immigrant Building, Ellis Island, New York Harbor, c.1904 


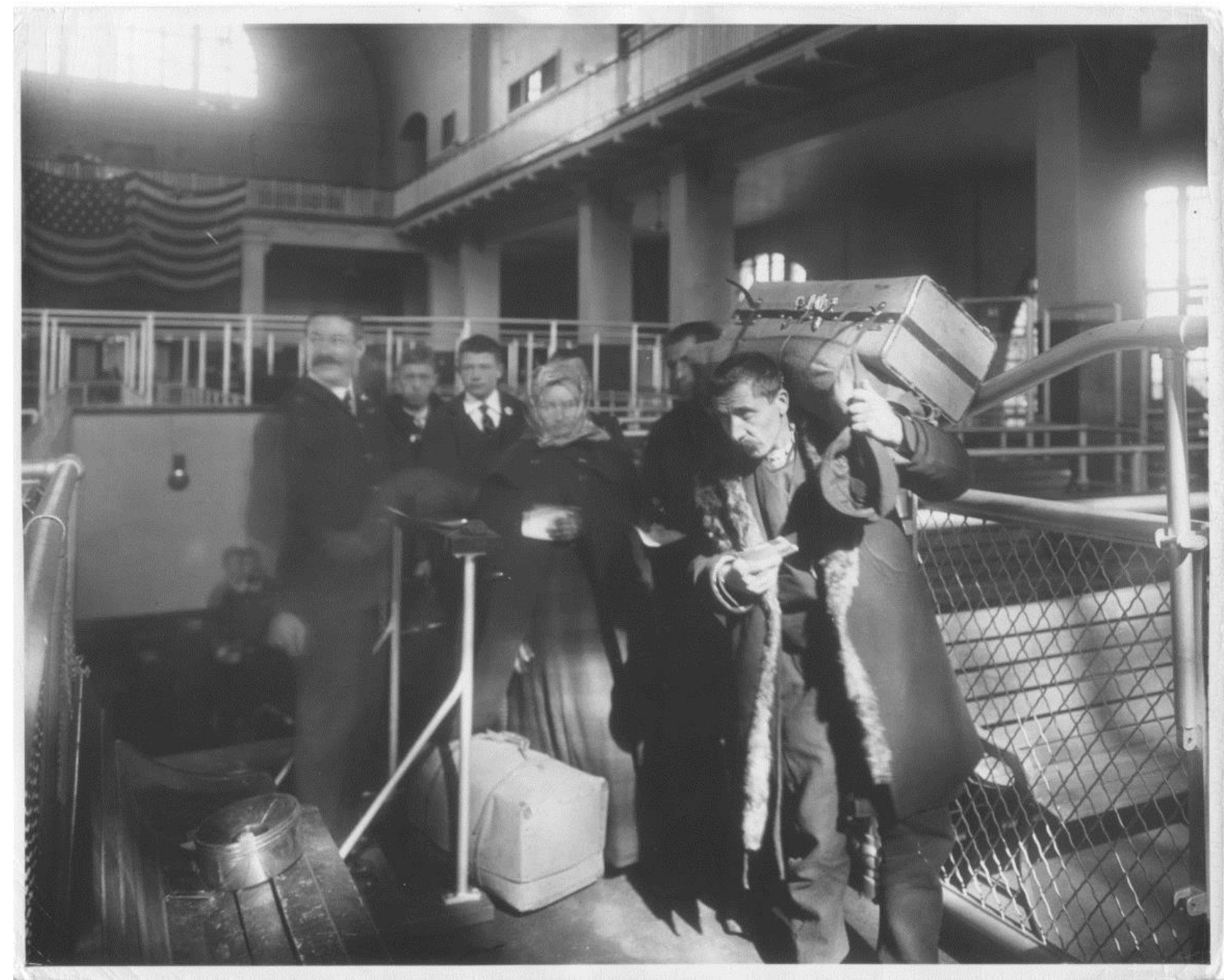

Figure 3 - First examination upon entering Ellis Island - Top of the Stairs, c.1890-1924 


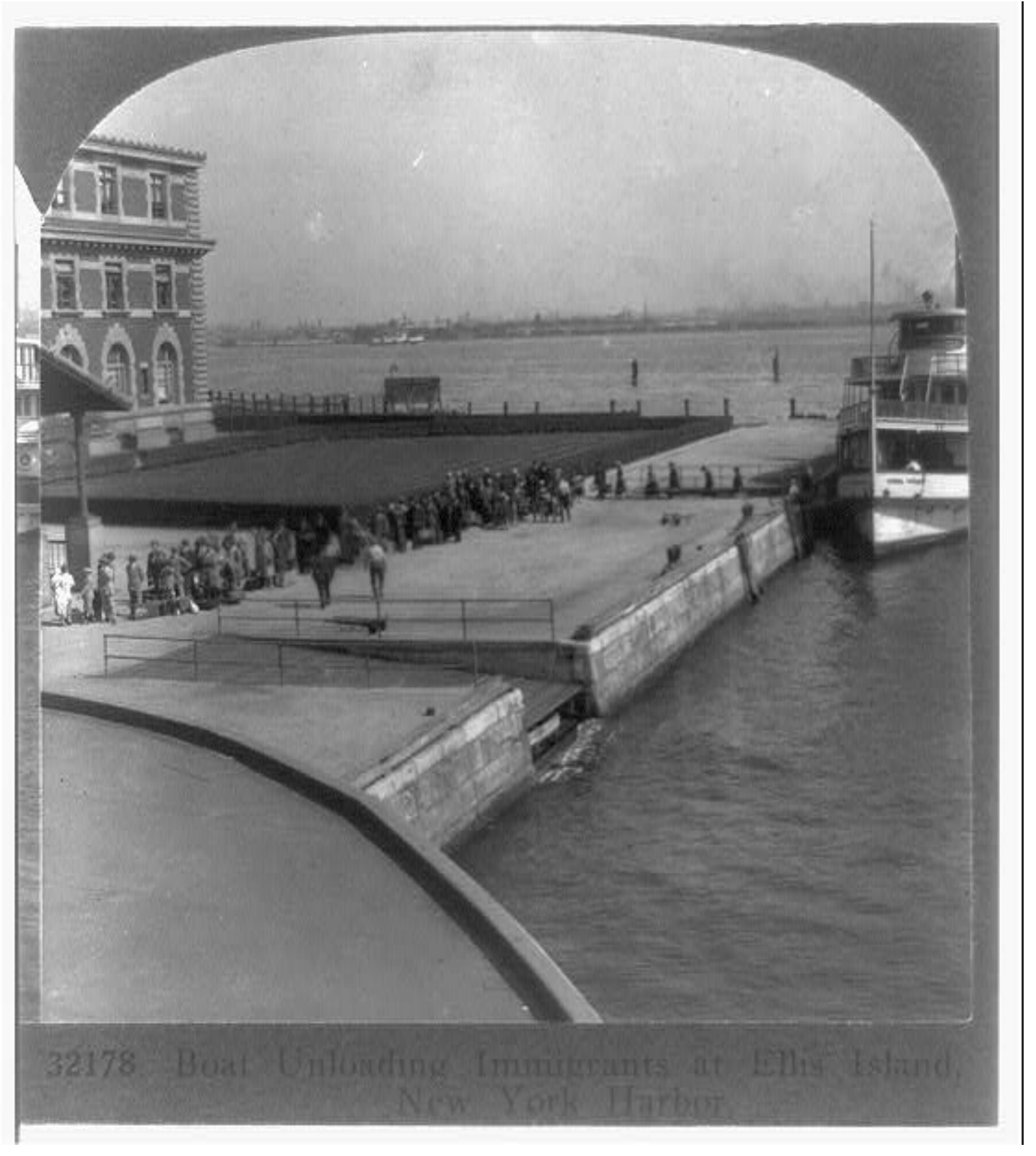

Figure 4 - Boat Unloading Immigrants at Ellis Island, New York Harbor, c.1890-1928 


\section{Bibliography}

Bayor, Ronald H.. Encountering Ellis Island: How European Immigrants Entered America. Baltimore: John Hopkins University Press, 2014.

Brownstone, David, Irene Franck, and Douglass Brownstone. Island of Hope, Island of Tears. New York: Rawson, Wade Publishers, Inc., 1979.

Cannato, Vincent J.. American Passage: The History of Ellis Island. New York: Harper Collins, 2009.

Coan, Peter Morton. Ellis Island Interviews: Immigrants Tell Their Stories in Their Own Words. New York: Barnes \& Noble, 1997.

Conway, Lorie. Forgotten Ellis Island: The Extraordinary Story of America's Immigrant Hospital. New York: Harper Collins, 2007.

EI-033, Emanuel (Manny) Steen, March 22, 1991. Interviewed by Paul E. Sigrist. U.S. National Park Services, Ellis Island, Oral History Online. Accessed on March 4, 2015. http://www.nps.gov/elis/learn/historyculture/upload/Manny_STEEN.pdf

EI - 193, Josephine Garzieri Colloway, June 17, 1986. Interviewed by Judith Hartman. U.S. National Park Services, Ellis Island, Oral History Online. Accessed on February 25, 2015. http://www.nps.gov/elis/historyculture/upload/Josephine Garzieri CALLOWAY.pdf

Figure 1 - Underwood \& Underwood. U.S. inspectors examining eyes of immigrants, Ellis Island, New York Harbor, c.1913. Library of Congress Prints and Photographs Division,Washington, D.C. http://www.loc.gov/pictures/item/97501532/. Stereograph. Accessed on March 4,2015.

Figure 2 - Underwood \& Underwood, Immigrants just arrived from Foreign Countries Immigrant Building, Ellis Island, New York Harbor, c.1904. Library of Congress Prints and Photographs Division, Washington, D.C. http://hdl.loc.gov/loc.pnp/cph.3a17784. Stereograph. Accessed on March 4, 2015.

Figure 3 - Photographer Unidentified, Top of the Stairs, c.1890-1924. From Save Ellis Island Collection, New York. http://www.saveellisisland.org/gallery/historic-ellis-island/. Accessed on March 4, 2015.

Figure 4 - Photographer Unidentified (likely Underwood \&Underwood), Immigrants to the United States, c.1890-1928. Library of Congress Prints and Photographs Division, Washington, D.C. http://www.loc.gov/pictures/item/2004681193/. Stereograph. Accessed on March 4, 2015. 
Kraut, Alan. "Doing as Americans Do: The Post Migration Negotiation of Identity in the United States." Journal of American History, 101 (2014): 707-725. Accessed on February 1, 2015.http://ogin.ezproxy.library.ualberta.ca/login?url=http://search.ebscohost.com/login. aspxdirect=true $\& \mathrm{db}=\mathrm{hlh} \& \mathrm{AN}=101035136 \&$ site $=$ eds-live $\&$ scope $=$ site

--. Silent Travelers: Germs, Genes and the 'Immigrant Menace'. New York: BasicBooks/Harper Collins Publishers Inc., 1994.

"Landed on Ellis Island: New Immigration Buildings Opened Yesterday." New York Times, January 2, 1892. Accessed February 2, 2015. http://login.ezproxy.library.ualberta.ca/ login?url=http://search.proquest.com/docview/103617814?accountid=14474

Markel, Howard. "Before Ebola, Ellis Island's terrifying medical inspections." PBS News Hour, October 15, 2014. Accessed March, 4, 2015. http://www.pbs.org/newshour/updates/octo ber-15-1965-remembering-ellis-island/

Medline Plus."Trachoma” Accessed April 3, 2015. http://www.nlm.nih.gov/medlineplus/ency/a rticle/001486.htm

Moreno, Barry. Encyclopedia of Ellis Island. Westport: Greenwood Press, 2004.

Parascandola, John PhD. "Doctors at the Gate: PHS at Ellis Island." Public Health Service Chronicles: Public Health Reports, Historical Perspectives on Public Health Issues. 113 (1998): 83-86.

Photographer Unidentified, Doctor's examination - stopping an emigrant suspected of defective eyesight. He will be detained for further examination, to ascertain if this defect would prevent him from earning a living, 1902. Library of Congress Prints and Photographs Division, Washington, D.C. http://www.loc.gov/pictures/item/93512778/. Photo mechanical print: halftone. Accessed on March 4, 2015.

Pitkin, Thomas. Keepers of the Gate: A History of Ellis Island. New York: New York University Press, 1975.

Terence V. Powderly, "Immigration's Menace to the National Health." North American Review, 1902: 53-60. In Major Problems in the History of American Medicine and Public Health, edited by John Harley Warner and Janet A. Tighe, 241-244. Boston: Houghton Mifflin Company, 2001.

Yew, Elizabeth M.D.. "Medical Inspection of Immigrants at Ellis Island 1891-1924.” Bulletin of New York Academy of Medicine 56 (1980): 488-510. Accessed on March 4, 2015 http://www.ncbi.nlm.nih.gov/pmc/articles/PMC1805119/ 